an amplification of what I said on Nov. 4th; and further, that I alone am responsible for every opinion, statement, and inference contained in it; not a single member of Council or official connected with the College had the faintestidea that such a pamphlet would appear. With me rests the sole responsibility of its publication, and of its circulation amongst the Fellows. "Laudatur abhis, damnatur" $a b$ illis," might well be its motto; for if, unhappily, it has provoked the hostility of "Flistoricus" and his allies, I am consoled by the commendations it has called forth from those whose opinions I most value.

Dec. 14th, 1886.

I am, Sir, yours faithfully, JoHN ERIC ERICHSEN.

\section{To the Editor of THE LANCET.}

SIR,-The thanks of every Member of the College of Surgeons are due to "Historicus" for his brilliant rejoinder to $\mathrm{Mr}$. Frichsen in your last issue. No more opportune moment could have been chosen for this reply than the eve of the poll that the Council of the College is taking of its Fellows, on the subject of what is now popularly called the "Members' Franchise." Mr. Erichsen has, we understand, in a mistaken sense of duty, sent to every Fellow a copy of his speech at the College on the 4 th, or rather of what that speech might have been if time had permitted on that occasion; and now that the other side of the question is thus clearly brought home to them, the Fellows will have an opportunity of forming an unbiased judgment ; attack and defence are each set fortb, and for the present the matter is in the hands of the Fellows. The Association of Members has not thought it to be becoming to go cap in hand to beg for the votes of the Fellows; but what a body of men cannot gracefully ask for itself may, without loss of dignity, be asked for by others. If the result of the poll is adverse to our claims - as it may be from the fact that the College Council has not seen fit to lay the entire resolution adopted at the general meeting before the Fillows,we have still the Privy Council to approach, and, if that body should not grant our petition, we have, beyond that, the Houses of Parliament. We trust, however, that in the College itself this reform may be carried out, and that when the Privy Council is approached it may be by a united body, the President and Council praying that the new Charter may contain the provisions we desire. For our own part, we have always endeavoured to keep the issue simple, and, leaving aside all questions of change in other corporations and colleges, shall continue to ask for reform in our own College of Surgeons, and that alone. When that is accomplished, it may be that other corporations will be only too anxious to follow a good example, and their councils, anticipating the desires of their diplomates, themselves throw open the portals. But one door is sufficient for us to knock at.

We are, Sir, your obedient servants,

WARWICK C. STEELE,

WM. AsHToN ELLIS,

Hon. Secs. Association of Members of the Royal College of Surgeons.

\section{THE FELLOWS, MEMBERS, AND COUNCTL OF THE ROYAL COLLEGE OF SURGEONS. \\ To the Editor of THE LANCET.}

SiR,--As a Fellow of the Royal College of Surgeons, I have been asked to answer two questions: 1 . Whether in my opinion, Members should have a vote for the election of the Council? 2. Whether, in my opinion, Members ought to have seats on the Council? I have answered the latter "question by a decided "Yes." The Members are a highly educated and able body of sưrgeons. The average Member of to-day is probably he equal to, or perhape the superior, of the average Fellow of twenty years ago (about my own standing). From their ranks many able men of ripe experience might be picked whose services on the Council might be invaluable to the College. The other question I have answered in as decided a negative. "Historicus" argues, in your columns, from the history of the College prior to the present century that the Members have a "moral right" to the so-called "franchise." This is beside the question. The real question is: "What is the best way of electing the Council of the great College which has charge of the interests of the profession of surgery?" I do not think that, although from what I have already said as to the propriety of Members having seats on the Council it will be understand that I cordially admit their fitness to exercise the franchise, the proposed concession would give them real representation, or that it would tend to improve the quality of the Council. In such a constituency as is proposed, an election would be followed by one of two results : either the seats on the Council would be placed at the disposal of the larger medical schools, or they would be at the mercy of some powerful association. As a matter of fact, a recent experiment in what is practically an almost identical constituency has proved that the latter of the two alternatives would operate. Reference to page 1172 in the current number of the Journal of the British Medical Association will show that such a result was actually calculated upon by the moving spirits of the Association. I find no fault with the list of able men who have been, through the influence of the Association, selected to represent the profession in the Medical Council. I am prepared to go further, and say that no other body than the British Medical Association, as at present constituted, could be better entrusted with the appointment of representatives of the profession. I submit, however, that the appointments of so-called representatives through the influence of a powerful Association is not representation at all. I am a member of the Association; I cordially acknowledge the useful work it has done and is doing, and I believe that it still has much useful work before it; but the life history of all Associations should teach us that the day will come when it will not be safe to entrust the control of the affairs of a great institution like the College of Surgeons to its waning vitality. In framing its new Charter, the College will have to legislate not only for to-day but for the future. The remedy for the alleged abuses in the present constitution of the College will not be found in direct (so-called) representation. 1 must confess to a feeling that to a certain extent the grievances of the Members are more sentimental than real. Those who are out of office look on things with very different eyes to those that are in. I can remember the time when some of those now on the Council were clamouring for reforms of which riper experience and a closer insight into the affairs of the College have convinced them of the inexpediency. Thus the reformers of yesterday become the Conservatives of to-day. Still there may be room for reform. Certainly the Council is not infallible; witness its present mistaken attitude towards the Apothecaries' Company. Something ought to be done to make things pleasanter between the Council and the Members. The admission of Members to seats on the Council would do something. To supplement this, I think that a scheme of indirect representation might be devised, which, while respecting the "moral rights" of the Members, would secure the election of a fairly representative Council. I would suggest that under the new Charter Members should take part in the formation of the elective constituency. Thus: let the Honours Examination for the Fellowship continue, as at present, to entitle to the franchise, but let the Members have the privilege of electing, honoris causâa, a certain number of Members of not less than ten years' standing to the Fellowship With such a provision, and the concession to the Members of the privilege of sitting on the Council, a sound representation would, I think, be secured.

I remain, Sir, yours faithfully,

Rowlands, St. Mary Cray, Dec. 13th, 1886. $\quad$ C. H. ALLFREY.

\section{To the Editor of THE LANCET.}

SrR,-The circular addressed to the Fellows of the Royal College of Surgeons does not fairly place before them the issue upon which their opinion is asked. In answering it, however, it may be put right by adding the words "if of ten years' standing" to the first question, and "if of twenty years' standing" to the second. Whilst I have no doubt as to the propriety of admitting the Members to the franchise, I do not think it at all necessary to give them the privilege of a seat on the Council. There are a great many Fellows scattered all over the country, occupying a high scientific as well as social position, who are general practitioners, and quite competent to safeguard the interests of the professicn 
in all respects, if elected to the Council ; and in my opinion it would not be wise so greatly to enlarge the area of selection as would be the case were the second proposition carried into effect.-I am, Sir, yours obediently,

Norwich, Dec. 15th, 1888.

THos. W. Crosse, F.R.C.S.

\section{To the Editor of THE LaNCET.}

SIR, - The circular from the College of Surgeons to ascertain the opinion of the Fellows upon the vital principle of representation of Members upon the Council has been issued, and I venture to say is found by most of an unsatisfactory character. These are the questions asked:(a) In your opinion should Members of the College be allowed to vote for Fellows as members of the Council? (b) In your opinion should Members of the College be eligible for seats on the Council? In answering them I hope each Fellow will ignore the unqualified nature of the questions, and state his views more broadly, and rather with reference to the resolution submitted and carried at the last general meeting of the Fellows and Members on Nov. 4thviz., "That it would conduce to the welfare of the College, and tend to promote the interests of medical polity an education- $(a)$ if Members of ten or more year's standing were empowered to vote (separately or conjointly with Fellows) in the election of the Council; and $(b)$ if Members of twenty or more years' standing were eligible to sit in the Council to the extent of not more than onefourth of the Council." I would also ask the Fellows to take this opportunity of expressing their opinion on the action of the Council in lowering and depreciating the status of the Fellowship, by the adoption of a modified examination to Members of a certain standing - a measure inflicting great injustice upon the younger Fellows (especially the provincial ones) in many ways, though perhaps of little moment to those senior ones who hold seats on the Council. The Fellowship was an evidence of a thorough anatomical and surgical knowledge, and to obtain it extra years of study were required, often involving no little sacrifice. The profession and the public relied upon it. It will be so no longer. By their action in this, and by their conjoint action with the College of Physicians in refusing to-coperate with the Apothecaries' Society to bring about practically a one-portal system for London (so much to be desired by all who have the welfare of the profession at heart)-by these two acts alone the Council have shown their inability "to read the signs of the times," and have forfeited the confidence of not a few of their present constituents. The time has come when a radical change in the management of the College is not only desirable, but absolutely necessary. I could have said much more on both the above topics, but fear to trespass on your valuable space. The legal right of Members has been so fully discussed that further comment is unnecessary. In conclusion, I will mention briefly a few of the alterations that might fairly be conceded, and which would probably benefit the College, its Fellows, and Members. (a) The Council to consist of three-fourths Fellows elected by Fellows only, and one-fourth either Fellows or Members elected by Members only. Voting-papers to be permitted. (b) The president of the College to be a Fellow or Member of a certain standing, and elected annually at a general meeting of Fellows and Members. (c) The recent modifications affecting the status of the Fellowship to be abolished. The Council to have the privilege of recommending not more than two members of the profession distinguished in surgery for election to the Fellowship at each annual meeting. (d) No alteration to be made in the Charter without consulting the Fellows and Members at a general meeting to be called for that purpose.

December 16th, 1886 .

I am, Sir, your obedient servant

F.R.C.S.

\section{To the Editor of THE LANCET.}

SIR,--Your leading article in this week's issue must echo the sentiments of many provincial Fellows. For some years the academic status of the diploma has degenerated. Not only has the preliminary educational standard been lowered, but even the Primary has been rendered easier by giving a selection of questions to be answered instead of the compulsory "all four" as formerly obtained. Now the Council, without consulting the general mass of Fellows, propose to still further depreciate the title by admitting, without any test of their fitness for such an academic distinction, a certain number of Members annually, and, secondly, to admit any Members of fifteen years standing to the Pass without subjecting them to what you have justly called the pons asinorum of aspirants - the dreaded Primary. What privileges have the general mass of provincial Fellows? They care little about the rights of voting, and a seat on the Council as is rightly urged in your leader, is within the reach of a very small minority. Have they ever been consulted on vital questions relating to the College till this last week? The chief privileges, then, of provincial Fellows are the academic distinction and status the title gives them. How ever wisely and delicately the proposals of the Council are carried out, many an injustice would be done to Fellows in small provincial towns, where the value of the Followship has begun to be appreciated. An imaginary case may easily be drawn. An M.R.C.S., through hard work and local influence, has acquired a large practice; he is a good allround man, but not in any way well read or of any scientific learning. He is acquainted with many London Fellows from having sent them cases up from the country periodically. Without the slightest trouble he would receive the highes: honour the College could confer on him, without ever having read for or passed anything but a minimum examination Not only does he suddenly become the academic equal of the man who has devoted three or four years to the acquisition of the title, but he really becomes his superior for it cannot but get bruited abroad that the Fellowship was conferred on him because he merited it, whilst the other man only got it by examination, and any man can pass examinations who has (not necessarily brains) but time, money, and applicability. Where then would be Sir Benjamin Brodie's explanation of the origin and institution of Fellows? It seems as if the London Fellows (as represented by the mass of the Councily hope to retain their vested interests by simply diluting them with a batch of new Fellows. The provincial Fellows, on the other hand, wish the integrity of the title to be maintained, or, if possible, made more select still. Let the Members have their electoral rights, and let them even have a chance of a seat on the Council under certain restrictions, and what have the Council to fear? The following two paragraphs, taken from a letter signed "Historicus," in your issue of Dec. 11th, deserve repetition and re-repetition: "The academic status (of the Fellowship) is being persistently debased in the silly hope of allaying the disaffection of a few Members by the offer of a cheap but degraded Fellowship"; and "The truth is, that the intellectual and professional prestige of the Fellowship is being seriously prejudiced by its forced association with an exclusive and obnoxious electoral privilege-a privilege, be it remembered, which is also an usurpation."

Dec. $13 \mathrm{th}, 1886$ I am, Sir, yours faithfully,

\section{THE HOSPITAL FOR WOMEN, LIVERPOOL. To the Editor of THE LANCET.}

SrR,-I shall feel much obliged by an early insertion of the enclosed in THe LANCET.

I am, Sir, yours faithfully,

Rodney-st., Liverpool, Dec. 12th, 1886. J. CAMrron, M.D.

4, Rodney-st., Liverpool, Dec. 12th, 1886.

DEAR SIR, - In a letter addressed to you by Dr. Imlach, and published in THe LANCET of the 11th inst., my resignation as a member of the "Hospital Inquiry Committee" is referred to in the following ambiguous terms:- "On March 8th, Dr. Cameron visited the Hospital for Women as one of the delegates from the Inquiry Committee. In the prerence of yourself and the vice-president, the case-books, hospital registers, and various memoranda were examined, and the lady superintendent and nursing staff subjected to a severe cross-examination. At the next meeting of the Medical Institution, he resigned from the Inquiry Committee, declining to serve any longer." To prevent any misunderstanding, I venture to trouble you with an explanation of the cause (omitted by the writer) of my resignation. After my visit with Dr. Alexander to your hospital, Dr. Imlach was taken seriously ill, and for a time his life was in extreme danger, and I was reluctant, under these circumstances, to continue an inquiry which, by the anxiety it was likely to occasion, I feared would aggrarate his condition. I 